\title{
The Celtic blue note: jazz in Neil Jordan's 'Night in Tunisia', Angel and The Miracle
}

\author{
MARIA PRAMAGGIORE
}

1 Noel lgnatiev How the /msh Became White iNew York Routledge 19951 p 1

2 Celtic dreamer' Film treland no $34(1993)$ p 20
Noel Ignatıev's How the Irish Became White, a provocative study of how Irısh Catholic immigrants, "[who were] an oppressed race in Ireland, became part of an oppressing race in America', begins with a statement made by Frederick Douglass in 1843:

The Irish, who, at home, readily sympathize with the oppressed everywhere, are instantly taught when they step onto our soll to hate and despise the Negro. . Sir, the Irish-American will one day find out his mistake ${ }^{1}$

Ne1l Jordan, Ireland's most prolific and most internatıonally promınent filmmaker, complicates Douglass's observation about the ready sympathy of the Irish in a 1993 interview in Film Ireland. When questioned about his use of black actors in Mona Lisa (1986) and The Crying Game (1993) Jordan replies:

I used Forest Whitaker because just about every black Britısh soldier has been to Northern Ireland, where they're subjected to a lot of overt racism I suppose because Insh people have never liked other minorities ${ }^{2}$

This paper aims to map the constellation of identificatıon, objectıficatıon, voyeurısm, mınstrelsy, appropriatıon and ventriloquism which gives voice and visual form to this sympathy and to this racism. I am interested specifically in contemporary Irish film and its practitioners' obvious fascination with African-American 
3 See Kevin Rockett Culture, industry and lrish cinema in J Hill $M$ Mcloone and $P$ Hainsworth (eds) Border Crossing (Antrim Instutute of Irish Studies/Britısh Film Insutute 1994) An Irish film studio in L Gibbons and J Hill (eds) Cinema and treland (Syracuse Syracuse Universıry Press 1988)

4 Luke Gıbbons Unapproved roads Ireland and post-colonial identity in Transformations $m$ irsh Cutture (Cork Cork University Press 1996) p 176

5 Krin Gabbard Jammin at the Margins Jazz and the American Cinema IChicago Chicago University Press 1996) p 43 culture. The history of Irısh film culture suggests that the 1980s and 1990 s are probably the most important decades for the study of Insh 1mages of Ireland, not least because of economic incentives for indigenous production and opportunities for finance from British and US sources. ${ }^{3}$ Within the context of an emerging internationalized Irish film culture, filmmakers such as Alan Parker (The Commitments [1991], based on Roddy Doyle's novel) and Gillies MacKınnon (The Playboys [1992], written by Shane Connaughton and Kerry Crabbe) have made allusions to African-American culture in overt and subtle ways in their films about Ireland In this essay, I examine the Africanist identity figured in repeated references to African-American jazz music in Neil Jordan's 1976 short story 'Nıght in Tunisia', in his first feature film, Angel (1982), and in The Miracle (1990)

It should not be surprising that a commercial and/or critical Irish cinema would engage with images and issues from US film and culture, since Hollywood is responsible for most twentieth-century cinematic images of Ireland. What I will argue more specifically, however, is that Jordan addresses experiences and effects of cultural alienation by invoking the (generally absent) figure of the African-American jazz musician. Jazz music, played by Inish musicians, is thematically and structurally central to Angel and The Miracle, which allows Jordan to allegorize what are often perceived as similar, if not shared, histories of cultural theft, enslavement and subjugation. Jordan calls up experiences associated with colonıal oppression, including an anxiety surrounding the question of origins, a rejection of linear history, the neocolonial influence of US mass culture, and the peculiar configuration of genders and sexualities under colonialısm

Jordan's use of jazz music thus appeals to a shared experience of alienation, to the common experience of being rendered a foreigner in one's native land. As Irish histonan and cultural theorist Luke Gibbons writes.

[t]here was no need to go abroad to experience the 'multuple identities' of the diaspora valorized in post-colonial theory the uncanny experience of being a stranger to oneself was already a feature of life back home ${ }^{4}$

Jordan's fiction and films also point to the history of Irish and Irish-American contact with African-American culture. For example, Krın Gabbard, writıng on jazz in American film, speculates upon the disproportionate representation of Inish immigrants as minstrel performers:

[It was] perhaps the one ethnic group in the US whose members could identify with the powerlessness and poverty of blacks durnng the first decades of the nineteenth century.

Clearly, there are problems assocıated with makıng neat analogies 
6 Tons Morsisan Planng in the Dark Whiteness and the Literary Imagination (Cambridge MA Harvard University Press 1992) between Irish and African-American experience, but I am less interested in establıshıng the relevance of the comparison than in examıning the textual and political significance of Jordan's repeated and explicit appropriations of jazz. Jordan's invocation of jazz partly conforms to the model forwarded by Ton Morrison that of the Africanist identity as structurng absence. ${ }^{6}$ But I will also argue that, thematıcally, Jordan's jazz is a means of expressing male sexuality and violence and, as such, may reinscribe notions of the spontaneity, expressiveness and hypersexuality of the black male performer even as it constructs a potentially unsettling hybridized postcolonial masculınity In the course of paying homage to jazz figures such as Charlie Parker and Louıs Armstrong through his young male Irish protagonsts, Jordan's films evoke stereotyped associations,

recirculatıng primitivist assumptions of jazz's spontaneous voicing of the soul and the utopian fantasy of the jazz soloist's ability to assert individualısm withın a group structure. The Irish jazz musician's performative deployment of masculinity is oral and phallic, expressive and exhibitionistic, and based on problematic images of black performers. However, the sexuality associated with jazz suggests a simultaneously pre- and post-Oedipal masculinity that is distinguishable from the avalable colonial modes of paternalistıc authority or the insufficient, emasculated Irısh 'paddy'.

Moreover, in formal terms, Jordan does 'signify' upon the jazz tradition by using the music to direct visual style and narrative form, thus translatıng jazz into film style. Jordan's editing adapts to the rhythm, pace and colour of jazz, ultumately undermınıng narrative coherence and chronological time. These interventions into narrative form - the structural centrality of jazz - underscore thematic anxietıes regarding 'impure' cultural or biological ongins and nonlinear history Film theories dealıng with narrative disruption have tended to focus on the visual spectacle of female sexuality. In 'Night in Tunisia', Angel and The Miracle, however, visual and, primarıly, auditory 'specularity' defer or short-circuit narrative trajectories, reorganizing the film according to repetition and revision around narrative and visual ellipses, which is consistent with the films' thematic concerns with cultural and personal loss.

\section{Angel of death: 'Strange Fruit' and 'Danny Boy'}

Henry Louıs Gates argues that jazz music provides one salıent example of signifying, which he defines as the double-voiced quality of a text that speaks to other texts. In particular, he writes,

black jazz musicians . . perform each other's standards on a joint album, not to critique these but to engage in refiguration as an act of homage .. this form of the double-voiced implies unity and resemblance rather than critique and difference.'
Signifying Monkey (New York Oxford University Press 1986) p xxviı 
8 Cited in Richard Keamey Avenging angel an analysis of Nell Jordan $\mathrm{S}$ first Irish feature film Studies an Irish Quarterly Revew no 71 (1982) p 302

9 Morrison Playing in the Dark pp $9-10$

10 Gabbard Jammin at the Margins $\rho 2$

11 Ibad p 45
Jordan locates himself withın the jazz tradition in order to pay respect to African-American jazz musicians and to foreground resemblances between Irish and African-American experiences of polıtical and psychological repression In an interview published in the Irish Times, in which he discusses his choice of the Billie Holıday/Lewis Allan song 'Strange Fruit' as the musical centrepiece for Angel, Jordan suggests

You could almost transpose the whole lyrics over to Ireland ... there you're speakıng about a situation where human beıngs kılled people they didn't know for reasons which had nothıng to do with any kind of human emotion whatever It was just to do with racial differences; and it's a sımılar kınd of situation that I was talkıng about in the film.

The Africanıst presence in this instance is utılized as the absent but masterful original composer and performer; the Inish musicians and filmmaker signify upon that tradition, ımprovizıng upon the song's associations. In Jordan's work, the disembodied African-Amencan 'speaks' through his or her music, which would appear to complicate Tonı Morrison's paradıgm whereın the Africanıst presence must be silenced and erased In the American literary tradition, Morrison argues:

to notice [race] is to recognize an already discredited difference To enforce its invisibility through silence is to allow the black body a shadowless participation in the dominant cultural body.'

Invisibility and disembodiment in Angel, 'Night in Tunisıa' and The Miracle is enforced - there are no African-American characters but silence, ostensibly, is not, for the jazz music is central to the protagonists' identities.

The apparent inclusion of African-American voice through music Is, If not undermined entirely, at least tempered by the fact that the music - as it is rendered by Jordan's young male saxophone-playıng protagonists - is the means by which adolescent, repressed masculine sexuality and its relation to violence is explored In the process, primitıvist associations 'idealızıng a black other as spontaneous, transgressive, and ecstatically free of bourgeois restraint' are played out ${ }^{10}$ Thus the African-American 'voice' turns out to be audible but non-verbal, expressive yet indetermınate; marshalled in the service of sexuality. The displacement and appropriation permıt Jordan's characters, as well as readers and viewers, to enjoy the auditory pleasures of mınstrel performance, to 'consume fantasies of black male sexualıty mediated through white performers'."

Jordan's choice of jazz music is not without historical resonances of fantasy and rebellion for his local as well as for international audiences. Consider, for example, the war waged on dance halls and jazz musıc, two of Jordan's omnıpresent tropes, by Father Peter 
12 Quoted in Gibbons

Transformations in tish Culture. p. 101
Conefrey of Leitrim during the 1920s and 1930s, which culminated in a demonstration against jazz music in 1934. Father Conefrey associated socialist rebellion and sexual permissiveness with jazz, writing:

Jazz is an African word meaning the activity in public of something of which St Paul said 'Let it not be so much as named among you'. The dance and music with its abominable rhythm was borrowed from Central Africa by a gang of wealthy Bolshevists in the USA to strike at Church civilization throughout the world. ${ }^{12}$

It is thus against a backdrop of Catholic Church opposition to jazz, and a history of African-American social protest and resistance encoded within jazz styles and lyrics, that Jordan configures his male coming-of-age narratives.

In Angel, 'Strange Fruit' and 'Danny Boy' are the songs African-American and Irish, respectively - around which a narrative of violent death and equally violent revenge is played out. A young saxophonist named Danny (Stephen Rea) is befriended by a mute girl (Annie) prior to a performance at a rural dance hall near Derry called the Dreamland Ballroom. She waits outside for him after the performance, putting her hands over his eyes, revealing herself to him and making love with him in a concrete construction pipe near the entrance to the ballroom. Danny and Annie witness the apparently sectarian killing of his manager, then Danny watches as the masked assassins shoot and kill Annie and the dance hall

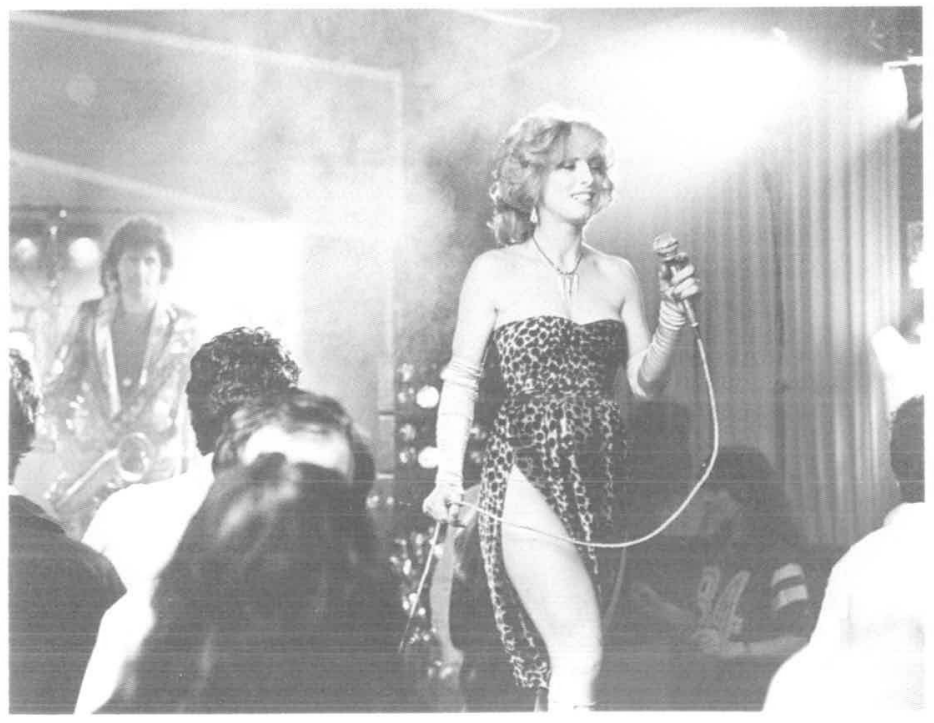
Screen $39 \cdot 3$ Autumn 1998 Maria Pramagg:ore . The Celtic blue note 
13 See Kearney Avenging angel

14 Richard Kearney Natıonalism and Irish cinema' in Transitions (Manchester Manchester Unuversity Press 1988), p 177

15 lbid p 179
16 The reference to Geu a white jazz musician makes Jordan s associations with AfricanAmerican jau non-exclusive However Geu can be distinguished from bop guru Charlte Parker the focus of Night in Tunisia by the fact that he was an extremely popular rather than esoteric performer Thus Jordan may be hıghlıghung the popular watered-down version of bop that Dannys pop/jan band plays explodes in flames The rest of the film is concerned with Danny's quest for revenge; he tracks down her killers one by one, becoming more like them, and also more anonymous, as he kills them. In the end, it becomes apparent to Danny that the police have allowed him to carry out this murderous spree of revenge because through it he leads them to the perpetrators, one of whom is a police officer himself.

Richard Kearney's excellent analysis of the film focuses on Danny's gradual substitution of violence for art, signified in a scene where he takes his saxophone from its case and puts a machine gun in its place ${ }^{13}$ Kearney argues that the film's strength lies in the way it addresses the psychological motivations for violence in a tımeless, almost mythıcal manner:

One of the strengths of Angel is its precise ability to focus on this 'basic mechanical level' of reflex attraction and recoil, symptomatıc of the workıngs of the subconscious. In this way Jordan investigates that fundamental nexus between aesthetic creatıvity and violence which has become one of the most frequent stamping grounds of contemporary art. ${ }^{14}$

Furthermore, Kearney emphasizes the manner in which the psychic undercurrents of the film shape its narrrative form, specifically noting that "while the deep-structure unfolds "synchronically" by repeating key visual and sound mottfs, the surface structure progresses "diachronically" according to the standard conventions of a sequentral plot'. ${ }^{15}$ Kearney identifies several critical motıfs which operate at a 'vertical (counter-narrative)' level, including dancing, music, the laying-on of hands and framıng images, notıng the recurrence of Verdi's Requiem, 'Danny Boy' and 'Strange Fruit'. Kearney, however, does not address in detall the effects of the diegetic performances and the non-diegetic jazz music on the film's narratıve, except to note the political implicatıons of the lyrics of 'Strange Fruit'. Extending Kearney's analysis, I would argue that the music in Angel - domınated by a jazz aesthetıc based on repetition and revision - underscores the themes of sexuality, loss and violence, and undergirds the film's formal and narrative circularity.

The film's opening credits are accompanied by a diegetıc saxophone riff played by Danny outside the Dreamland Ballroom. Annie touches the instrument and he tells her 'it's a saxophone'. The object, endowed with phallic status, is associated with Danny, 'the Stan Getz of South Armagh', as we see hım fondle, fiddle with and clean the instrument repeatedly ${ }^{16} \mathrm{By}$ the tıme Danny finds the gun hidden in his first victım's apartment, his assembling of the automatic weapon looks familiar because it visually and aurally parallels his frequent manipulation of the saxophone. Given the phallic associations of jazz instruments documented by Krin Gabbard 
and suggested in these scenes, it is not surprising that after the bombing of the ballroom a guilty and angry Danny has actually lost his alto saxophone and is afrand that he has lost the ability to play When he tells his Aunt May he has lost his saxophone, her reply 'We've all lost something' - emphasızes the metaphorical significance of the instrument.

One scene in particular underscores Jordan's use of jazz music as it insinuates itself into the idiom of his film language After leaving the hospital, Danny stays at Aunt May's house, discovering his uncle's soprano saxophone, which has been stored under a bed As he plays a mournful cascade of notes and looks out of the window, he visually revisits the scene of the kıllings in an increasingly rapid and repetitive editing sequence. Shots alternate between images of plenitude (the girl coverıng his eyes as she walks up behınd hım outside the dance hall) and violence (the murder of his manager; the burnıng dance hall) The riff begins with the following shot sequence: Annie's hands, Annie being shot, and a tıny bell tınklıng. As the music speeds up, growing more insistent and shrill, the saxophone repeats a phrase in sync with the images. The sequence peaks with the shot of Annie's hands repeated three tımes, and closes with the shot of the bell, suggesting that Danny's musical play of absence and presence organızes and revises his memory and loss.

Danny's encounter with Annie and her death become intertwined in memory, whereas previously his musicianship had been associated with sexual conquest alone. During the performance at the Dreamland Ballroom, Danny is the object of various female characters' visual interest, including that of Annie, a recent bnde, and the band's singer, Deirdre. Prior to the first gig, Danny propositions Deırdre, engages in flirty banter with the bride and finally makes love with Annie. After leaving the hospital and rejoinıng the band, Danny begins a love affair with Deırdre which is threatened by his increasing alıenation. He tells her his problem is 'like a nothıng you can feel, and it gets worse'.

Musicians and murderers are depersonalized in the film, and Danny's growing anonymity conflates violence and sexuality. When Deırdre tells Danny they'll be playıng his tune, 'Danny Boy', he replies, 'That's not my tune, that's everyone's'. Durıng theır flirtation at the Dreamland Ballroom, the bride asks Danny if she has seen him play before, to which he replies 'we all look the same' Later, Danny becomes sexually involved with her in order to locate her estranged husband, whom Danny believes was with the men who kılled Annie. She waits outside the dance hall in a repeat of Danny's encounter with Annie. As they compare Danny to the husband, they collapse sexuality (the reason he gives for his questions) and violence (the actual reason he asks them): 
Woman: I thınk you're jealous'

Danny: I want to know everything he ever did with you Am I like hım?

They kıss

Woman. You're lıke him now.

When Danny finds her husband the next day, he pulls a gun on hım. The interchange between the two men suggests their growing simılanty.

Danny: How'd you do it?

Man: It's not that hard when you put your mind to it. You may know yourself.

Danny How did you shoot her?

Man: It's easy, just pull the trigger.

Danny does pull the trigger, making the man hıs thırd victım Later, Deırdre will tell Danny that he is dead, and that he looks just like the police: 'them, like you, only in uniform'

Danny's loss of identity, the collapse of musician and murderer, is marked by an increase in the use of jazz riffs which signal the return of repressed memories, and by a decline in Danny's musical performances. Jazz riffs signal the repetition of previous events when the police approach Danny and take him to the morgue, when the bride tells of her husband's absence on their wedding night (the nıght Annie is killed), and just before Danny witnesses the new manager makıng protection payments (which is what brought the paramilitaries down on the previous manager).

It is fittıng, then, that a jazz riff sets the stage for the final confrontation between Danny and Bonner, the polıce officer involved in the paramilitary violence The film returns full circle visually and aurally; 'Here we are again', Bonner remarks as he drags Danny into the ruins of the Dreamland Ballroom. He makes the analogy between music and violence complete: 'It's a lot easier to play than the saxophone', he says of his gun, 'You only have the one tune'. The gun creates loss and the saxophone relives and revises the absence which becomes a presence' Danny's 'nothing that gets worse'.

Bonner is killed by his superior, Bloom, as Danny is returned to the position of witness to violence rather than perpetrator. Verdı's Requiem, the musical accompaniment to the initial scene of violent killing, is heard over the sounds of Bloom's helıcopter in the film's closing moments.

Jordan's use of jazz foregrounds the relatıonshıp between sexuality and violence Not only are the specific songs Danny performs connected to his struggle against violence and anonymity, but the non-diegetic score, resonant with Danny's replaying and revising the loss of Annie and his innocence, is critical to the film's antı-narrative elements and to Jordan's visual style 
17 Nell Jordan A Nell Jordan Reader Night in Tunusia and Other Stories (New York Vintage International 1993), p 34
18 Ibrd pp 42-3

\section{'Night in Tunisia': jazz combo as utopian family}

'Night in Tunisia', a clear precursor to The Miracle, deals with an unnamed adolescent boy negotiating his emerging sexuality and nurturıng his artistic talent in the context of vanous 'improper' famıly structures durıng two months at a seaside town. The boy's father, a professional musician, plays,

what he said would be his last stınt, since there was no more place for brassmen like him in the world of three-chord showbands.... Every night his father took the tenor sax and left for Mosney to play with sixteen others for older couples who remembered what the big bands of the forties sounded like. And he was left alone with his sister who talked less and less as her breasts grew bigger With the alto saxophone which his father said he could learn when he forgot his fascination for three-chord ditties. With the guitar which he played a lot, as if in spite against the alto saxophone."

The following themes - almost all of them circulating around the musical instruments in the story - are translated from the story into the film the absent mother; the father's profession as a swing-band hack and his desire for his son to play the saxophone; the generational nift between big-band swing and bop, signified by the alto saxophone, symbol of bop; the saxophone versus the guilty pleasure of the guitar; the incestuous displacements of erotıcism between the instruments and his sister, which also extend to an older unnamed girl with whom he and his sister have spent a night under a blanket on the golf course durng a previous summer stay.

Several passages from 'Night in Tunisia' highlight the sexual associations Jordan attaches to the Dizzy Gillespie composition which lends the story its title. When the boy first hears Charlie Parker's famous version of the song:

He heard the radio crackle over the sound of fallıng water and heard a rapid-fire succession of notes that seemed to spring from the fallıng water, that amazed hım, so much faster than his father ever played, but slow behınd it all, melancholy, like a river. He came out of the tollet and stood listening with his father Who is that, he asked his father. Then he heard the continuity announcer say the name Charlie Parker and saw his father staring at some point between the wooden table and the wooden holiday home floor. ${ }^{18}$

Lest the connections between the oral physicality of playıng the saxophone and sexuality be missed, the boy has already encountered a youth, a tall thin boy who "put his mouth to the mouth of the French letter and blew. It expanded, huge and bulbous, with a tiny bubble at the tip.' ${ }^{19}$ 
The saxophone and the condom suggest both orality and homoeroticism; however, the boy's preference for the saxophone and implicit rejection of overt homosexuality is revealed in a scene where the thin boy puts on a condom and masturbates In contrast to the sensual ımages of fluidity in Parker's playing, the boy notes the dead-end quality of autoeroticism and, implicitly, homoeroticism. 'He saw how the liquid was caught by the antiseptic web, how the sand clung to it when the thin boy threw it, like it does to spittle', ${ }^{20}$

Furthermore, the Parker solo freezes space and tıme by occupying both simultaneously and, unlıke the thin boy's 'antıseptıc web', the music is orgasmically transcendent:

The notes soared and fell, dispellıng the world around him, tracing a series of arcs that seemed to point out a place, or if not a place, a state of mind.... He decided it was a place you were always in, yet always trying to reach, you walked towards all the tıme and yet never got there, as it was always beside you ${ }^{21}$

The boy repeatedly encounters the older girl, to whom a less ambient, more phallic eroticism seems to cling, along with her yellow cardigan. The girl is represented in distinctly Nabokovian terms, suggestıng her sexual knowledge and her own incestuous family structure She plays tennis with an older man, without much interest on her part. When the game is completed, he hurnes her to a nearby car

She was standing on the one spot, dead-centre of the court, hardly lookıng at all at her opponent. She was hittıng every ball cleanly and lazily and the sound that came from her racquet each time was that taut twang that he knew only came from a good shot. . . And every now and then when the man she was playng against managed to send a shot towards the sidelines, she didn't bother to follow it at all. She let the white ball bounce impotent towards the wire mesh

He watched the small fat man he didn't recognize lose three balls for every ball won. He relished the spectacle of a fat man in whites being beaten by a bored teenage girl in sagging high heels ${ }^{n}$

The gırl, unlıke Lolıta, is also apparently suicıdal the boy 'learnt that underneath her frayed blouse her wrists were marked'.

After dissatisfying encounters with the thin boy and others like hım as they play on the beach, sınglıng out women to call 'whores', the main character returns home to the plano, 'trying to imitate that Charlie Parker's 'Night in Tunisıa' and finally picks up the alto saxophone, allowing his father to help him find the notes. 
He learned the first four keys that day and when his father took his own instrument and went out to his work in Butlins he worked out several more for himself. When his father came back at two in the morning, he was still playing ... He forgot the raft and the games of pontoon and the thin boy's jargon. He stayed inside for days and labonously transferred every combination of notes he had known on the prano onto the metal keys. He lost his tan and the gold sheen of the instrument became quickly tarnished with sweat, the sweat that came off fingers in the hot metal room $\mathrm{He}$ fashioned his mouth round the reed till the sounds he made became like a power of speech, a speech that his mouth was the vehıcle for but that sprang from the knot of his stomach, the crook of his legs. ${ }^{25}$

The boy masters his own new language of the body, his own jargon, with his father's help. He learns that the girl with marked wrists had been rescued by the lifeguard several tımes from 'a part of the beach too near the shore to drown in by accident', and he approaches her. He plans to tell her about 'that place' he has found in the music. In the final passage of the story, sex and saxophone, woman and water merge in a triangulated image of mutual oral engulfment and sexual aggression:

She raised her head and opened her mouth, her answer already there. She inhabited that place, was already there, her open mouth like it was for the lifeguard when he pressed his hand to her stomach, pushed the salt water out, then put his lips to her lips and blew. ${ }^{26}$

In these passages, wordlessly, water and sound, orality and sensuality are expressed in the fluid Parker style the boy imitates. The orality of his sexuality and his rejection of the other boys' games signify his adoption of the 'appealıngly unconventional paradigms of masculınity' that jazz presents. ${ }^{27}$ He becomes assertive, yet does not challenge his father in order to achieve mastery His masculınity cannot be associated with the controlling mastery of a colonial paternal figure or the emasculated colonized subject represented by his father And, interestıngly, thıs polymorphous sexuality seems to require a triangulatıon, a thırd term - the lifeguard's lips breathıng life into the cardigan-clad girl's mouth. ${ }^{28}$

Charlie Parker's playıng speed, and his improvizations from the top of the anchoring chord rather than the middle, are only two of the reasons he is recognized as the most important jazz soloist since Louis Armstrong. Parker, along with Dizzy Gillespie, is credited with the innovations of 1940 s and 1950s bop, a combo-centred style which depended upon instrumental virtuosity and improvization, both displayed in landmark and fetishized solos. ${ }^{29}$ The combo functioned, in utopian terms, as a community in which individuality and artıstry 
30 Luke Gibbons Identity without a centre in Transformations in Irish Cuiture op 142-3
31 Sylva Thomson Miracle man Irish Siage and Screen vol 3 $(1990 / 91)$ p 7
32 Gabbard Jammin at the Margins o 143 were prized - the polar opposite of the band the boy's father plays with for a living

In allegorizing the father-son relationship through jazz, Jordan points to a fantasy of unconflicted Oedıpality, and a community in which individuality is nurtured. The unmentioned missing mother is refigured as musical instrument; the father assists his son in his quest for physical and aesthetic transcendence rather than competıng with hım, and prepares the boy for consummation with Jordan's version of the sweater girl Curiously, the sister drops out of the story, displaced by the ephemeral music and the embodied and sexualized older girl.

The allegory of spiritually meaningful community and transcendent sexualıty made possible by African-American jazz artıstry is not simply an interesting feature of Jordan's analogy between African-American and Irish culture. As Luke Gibbons points out,

It is not simply. that allegory comes after the event, a mask that can be removed at will; it is part of consciousness itself under certain conditions of colonial rule..$^{30}$

Perhaps, then, displacing generational, political and sexual conflicts onto jazz in the story and the film is part of the consciousness of these works. One reviewer noted in Irish Stage and Screen that the 'only bond between the father and his son [in 'Night in Tunisia'] is their common love for Charlie Parker music and playing the saxophone' ${ }^{31}$ Perhaps, then, their common desire for an expressive, oral, performative alternative to conventional masculınity, their problematic negotiation of individuality and community, and their location of those desires and their realization in jazz, are all part of the formal structure of that bond and of the story.

\section{The Miracle: jazz as Oedipal spectacle}

If the artıstry of Charlie Parker, bop soloist par excellence, is the centre of the short story, the Hoagy Carmichael classic 'Stardust', made famous by swing soloist par excellence Louss Armstrong, is the set piece which mediates relations among the characters in The Miracle. Krin Gabbard remarks that 'members of Armstrong's band are sald to have referred to their accompanyıng figures on Armstrong's 1931 recording of "Stardust". as "the fuckıng rhythm" , ${ }^{32}$ and in this film version of the Freudian family romance, this rhythm, and the repetition and revision that characterize jazz form, revolve around the maternal body, which is no longer displaced and reshaped as a musical instrument as it was in the short story. In this tale of the return of the repressed maternal body, and the son's assertion of his sexuality and musicianship, the boy can achieve transcendence only through through the most literally 
33 This reversal echoes that of the Playboys in which the film version of Gone With the Wind is reenacted on stage transgressive sexual act: maternal incest. The form that the film's narrative assumes is an explicitly Oedipal scenario structured by jazz music.

In The Miracle, Jimmy's absent mother, whom he believes to be dead because this is the story told to him by his father Sam, returns to the seaside town of Bray Her reappearance disrupts the intact and continuous iıfe story Sam has crafted and complicates Jimmy's adolescent sexuality. Furthermore, her return rewrites Jimmy's bıological and cultural ongins because the surprising source of Jımmy's parentage is a problematic interpenetration of American and Irish popular cultures Renee Baker, the absent/present mother, is an American stage actress and singer, whereas the overly present, overly embodied father is an Irish musician who drinks too much.

Jimmy performs with his father in a dance hall for middle-aged couples, but resists being absorbed into the combo's repertoire, aware and resentful that it does not much matter what he plays because nobody is listenıng. He walks the boardwalk by day with his chum, a sisterly girl named Rose, whose histrionic claım that she and Jımmy are 'too friendly to be lovers, too close to be friends' belies her obvious feelıngs for him. Her phrase is an apt representation of the romance narratives she and Jimmy concoct on the boardwalk, as they use the other beachcombers as fodder for indulging in flights of verbal acrobatics In this manner, the film is framed by an attention to the way narratives are constructed.

Renee appears on the boardwalk one day, arriving by train from Dublin. Rose intiates the young couple's interest, wondering if she got off at the wrong stop, but it is finally Jimmy who is entranced by Renee The triangulation of this relationship is visually suggested in the scene of Renee's arrıval, when Jımmy and Rose follow her to the stairs leading to the beach and Renee is framed between them $J_{1}$ mmy pesters Renee when she visits the beach, rides the same train into Dublin and follows her to the Olympia Theatre where she is performing a stage version of 'Destry Rides Again', the 1939 US musical-Western featurıng Jımmy Stewart and Marlene Dietrıch. ${ }^{33}$ Jimmy steals a poster bearing her image and puts it up in his room. In repeated visits by train, Jimmy watches Renee playing the phallic Frenchy to her counterpart's non-violent Destry; she shoots, sings, smokes and ultımately dies taking a bullet intended for Destry. The nightly repetitions of her death and her blood-staned costume evoke her real and symbolic deaths in the film just as Jimmy's endless loops on the train signal his problematıc relatıonship to orıgin and destınation.

Jımmy's parents collude in keeping the secret from hım, but Renee and Jimmy's obsessive interest in one another leads Jimmy first to jealousy, then to the discovery of his prehistory, once again in a manner mediated by an image His access to the primal scene is 
34 Jordan s novel The Past deals with a man tiyng to reconstruct his ancestry from a sertes of photographs taken in 1914 Arguably, the photograph of Jody and Dil that Jody shows to Fergus while in captivity in the Cryng Game establisies Fergus s positions of desire and/or identification in relation to Jody and DH

35 Gabbard, Jammn at the Margins $p$ distinctly photographic; in typical Jordan fashion he finds a photograph of Renee and Sam in Renee's purse. ${ }^{34}$

If the psychodynamics of the men's relationship subtends the triangulated structures of the short story, the film's ventriloquism of sexuality and loss through jazz music results in a refusal of narrative progression other than by riffing, improvization and repetition. This circularity is certanly consonant with the film's self-conscious focus on the way stories and histories are constructed Gabbard warns, in relation to American cinema, that

As both psychoanalytic and structuralıst film theorists have pointed out, musical numbers bring the film's story to an abrupt halt Since narrative is indisputably what most audiences crave, then a film about jazz or a film with jazz cannot dwell on the music for too long. ${ }^{35}$

Jordan defies this convention in The Miracle, dwelling obsessively on jazz in full-length performances and in scenes during which the non-diegetic jazz score is privileged. Here, as in the short story, jazz music is no liberatory or creatıve outlet unless it recognizes the solo artistry of the performer, and/or the sexual expressiveness of the music Jimmy disdainfully rejects a job playing with his father's dance-hall ensemble for one accompanying a circus contortıonist, clearly enjoyıng the challenge of matching his playıng to her body's movements in rehearsal Continuing the sexualization of Jımmy's musicianshıp, Jimmy can be seen through the contortionıst's legs - framed in this way by the camera - durıng the public performance. As Rose's jealousy ignites, she leaves Jimmy to his own devices - travelling in seemingly endless loops of train windows accompanied by non-diegetic jazz music between the seaside town and Dublın At a post-performance party Jimmy accompanıes Renee as she sings 'Stardust', a song about invokıng memories.

Significantly, the camera circles Jimmy and Renee as he plays piano for his mother, just as it does in the scene where he plays for the contortionist

The scenes in which Jimmy spontaneously plays the saxophone for the acrobat and the prano for his mother have all the hallmarks of a Mulveyan spectacular image - they do not 'further the narratıve', but instead foreground the recirculation of music and rhythm as part of Jimmy's psychosexual investigation. After playing with the circus and for Renee, Jimmy dreams of spinning the rope for his mother as she crazily circles the tent above him while his father, and photographs of his father, burn nearby. These repetitive actions, underscored by jazz, shape the film as lack and its revision Jimmy is engaged in an extremely complex fort-da game He has experienced the lack of a mother his entire life, yet when he discovers near the film's conclusion that Renee is his mother, he learns a new register of loss - the loss of a mother who is not dead. 
36 Gates The Signifying Monkey, p 64

37 Luke Gibbons Lies that tell the truth in Transformations in lirsh Culture, pp 119-20

38 Luke Gıbbons, Race agaınst tıme racial discourse and lish history in Transformatrons in irsh Cuhure, p 157
39 Eamonn O Donnell The Miracle Film Base News (July-Aug 1991) p 22 And see Dents Staunton Nell Jordan s new film a his in Berin Irish Times 22 February 1991 p 10 (Scenes in the crrcus and on the theatre stage lend the film an old fashıoned look placing it in Neil Jordan s words "outside ime"
He must, in a sense, improvize the Oedipal conflict through that configuration.

Henry Louss Gates writes that 'Improvisation, of course, so fundamental to the very idea of Jazz, is "nothing more" than repetition and revisıon' ${ }^{36}$ And Luke Gıbbons, writıng on the Irısh film Maeve (Pat Murphy, 1981), associates narratıve redirection through repetition as a device which foregrounds the past as a destabılızıng force

In Maeve, landscape becomes one of the primary means of arrestıng the flow of events, becoming in effect a form of congealed memory. The apparent contınulty between past and present is brought out in the film by a series of flashbacks inserted into the narrative without the usual demarcating devices of blurred focus or dissolves - as if to say, in Maeve's own words, that 'the more you focus on the past, the more reality it gains' ${ }^{37}$

Gibbons further writes that,

the impossibility of gainıng direct access to the past is not because it is sealed off, as in a tıme capsule, but because it is part of an unresolved historical process which engulfs the present ${ }^{38}$

This view of repetition as a means of acknowledging the past as a process taking place in the present is extremely helpful for my reading of The Miracle. Jimmy deals with the return of the repressed lost maternal object in the present through his music, reliving, reınvoking, and rehearsing her absence and its relation to his desire. The saxophone and jazz music are his ventriloquists, as they are for the boy in 'Night in Tunisia' The privileging of the performance, and the insistence upon Jimmy's desire to perform for his object of desire, his mother, again suggests a refashioned masculinity at once oral, phallic and fetishized

As if the film's sense of time as repetition and revision extends to its mise-en-scene, several commentators have remarked that the look of the film is nostalgic, evokıng a sense of the $1950 \mathrm{~s}$

Renee is a glimpse of the exotic, a luminously sensual woman of a kınd seldom seen since the Fifties, and as such $J_{\text {Immy }}$ invests all his dreams and desires in her. ${ }^{39}$

Like the boy discovering the solos of Charlıe Parker for the first time, Jimmy's journey becomes detached from real time, and the various performance tımes in the film - Renee's, Sam's, Jimmy's, the circus - assume a heightened prominence as a result. And Jımmy's last performance is an extremely shockıng grand finale Jımmy and Renee have sex on the boardwalk after the secret has been revealed. 


\section{Maternal/paternal allegory}

In 'Night in Tunisia' and The Miracle narrative is short-circuited by obsessive, repetitive iterations of performance and theatricality, specifically in the idiom of African-American jazz music. In the film, as in improvization, jazz music admits of a troubled relationship to the past and produces a juxtaposition and proliferation of complementary and contradictory images without origin or destination It is interesting that a number of reviewers called The Miracle Jordan's 'home movie', as if its small budget and Irish shooting location secured his return to his proper ongin, because this is a film in which origins are mythologized and problematic, fetıshized and violated in an almost schizophrenic manner.

The formal narrative circularity, wherein the jazz performances, non-diegetic jazz and Jimmy's circular, neverending train rides structure the film in negatıve terms, suggests an anxiety of origins expressed through a musical language of loss The structure foregrounds the problem of obtaining access to any origin (bıological, ethnic, cultural) in a postcolonıal and postmodern context that increasingly recognizes the complexity of cultural hybridity. The absent mother, Renee, performs in a staged musical Western in the role made famous by Marlene Dietrich, significantly, Jimmy initially guesses that the mysterious, foreign woman is French while Rose believes she is English

The relationship between Sam and Jimmy is crucial and yet fraught; their shared love of jazz is both a means of connection and the site of their recognition of loss, in a different 'register of

40 Gibbons Ireland and postcolonal identity p 172 memory. ${ }^{40}$ In both works, stage, film, musical and circus performers invoke and critıque neocolonıal power relations, themselves often cloaked in parental metaphors, as they unfold in the culture of entertainment. The films do not directly address the issue of British ımperialısm or US neocolonialısm - rather, famılıal and communal structures are always already embedded within those polıtıcs. Thus any individual or cultural ongin - figured as paternal or maternal or as theatrical source material - is always elsewhere and always impure, refusing the postcolonial subject any linear cultural or ethnic genealogy. Thus Jordan's use of jazz music at once renders the peculiar connection his works assert between Irish and African-American cultures, and evokes their shared histories of loss and dislocation even as he points to the neocolonial influence of American music and popular culture as it operates in contemporary Ireland

Why Jordan is so interested in reworking colonial and neocolonial relations in Oedipal scenarios is an interesting question. I would argue that Jordan's reworkıng of Freudian/Oedipal tropes in The Miracle is grounded in certain historical events of 1980s Ireland events that make reference to a number of converging and implodıng 
41 I am indebted to Luke Gibbons for this insight and for the information he presented during a leciure at Northen Illinoıs Universitys Media and Culture in lieland seminar at Dublin City University July 1996

42 Celtic dreamer p 20

43 Miracle worker Insh Independent 4 Marci 1991 'traditions', such as the mythologized Irish family, the repression of female sexualıty and the problematıc category of Irish masculınıty. ${ }^{41}$ Jordan himself states that he

had an idea of using incest as an expression of rupture within a family, a prism where different aspects of what that implies are explored. mother-love, jealousy, sexual attraction ${ }^{42}$

and he suggests that the film

deals with a specifically Irish kınd of failure to understand women on the part of men It grapples with the inarticulacy that the male character needs in order to keep going. ${ }^{43}$

The oral and phallic sexuality of the boy in 'Night in Tunisia' is turned towards his mother with a vengeance in The Miracle suggesting the desire to both possess and destroy the maternal body. I would suggest that Jordan could no longer dispense with the mother's body in the film as he did in the story, because tensions surrounding marriage, abortion and female sexualıty reached crisis proportions during the 1980 s The maternal body became a contested entity in the 1983 abortion referendum, which made abortion illegal and unconstitutional, and during the 1984 events at Granard, where a fifteen-year-old pregnant girl who had told no one of her pregnancy died near a statue of the Virgin Mary. Her sister committed suicide a few months later. In that same year, the Kerry babıes incident occurred, in which a woman was accused of murdering a newborn baby found washed up on a beach in a blue fertilizer bag. A woman, Joanne Hayes, from whom a confession was extracted without a lawyer present, was later shown by DNA testing not to be the dead infant's mother. And in 1986, the divorce referendum concluded a series of events which had placed women's bodies, sexuality and lives at the centre of national debates about Ireland's modernization. For these reasons, I suspect, Jordan could no longer displace incestuous desire onto the saxophone, the maternal body had become a player or, perhaps, a pawn, in the allegorical struggle for national and sexual identity. 